This PDF is a selection from a published volume from the National Bureau of Economic Research

Volume Title: Women Working Longer: Increased Employment at Older Ages

Volume Author/Editor: Claudia Goldin and Lawrence F. Katz, editors

Volume Publisher: University of Chicago Press

Volume ISBNs: 978-0-226-53250-9 (cloth); 978-0-226-53264-6 (e-ISBN)

Volume URL: http://www.nber.org/books/gold-12

Conference Date: May 21-22, 2016

Publication Date: April 2018

Chapter Title: The Return to Work and Women's Employment Decisions

Chapter Author(s): Nicole Maestas

Chapter URL: http://www.nber.org/chapters/c13799

Chapter pages in book: (p. $55-83)$ 


\title{
The Return to Work and Women's Employment Decisions
}

\author{
Nicole Maestas
}

Husbands and wives tend to retire around the same time within couples. But because women tend to marry men older than they, the joint retirement of married couples means that married women retire at younger ages than their husbands do. This difference in age at retirement seems counterintuitive since women have longer life expectancies and have shorter careers due to delayed or interrupted labor force participation while raising children. ${ }^{1}$ Thus, they should optimally retire at older ages than men.

The observation that husbands and wives tend to retire at the same time, even when they greatly differ in age, has been noted in several different data sets for the United States and across different cohorts (e.g., Blau 1998; Coile 2004; Gustman and Steinmeier 2000, 2004, 2014; Hurd 1990; Maestas 2001; Michaud and Vermeulen 2011; Schirle 2008). Evidence of coordinated retirement behavior has also been documented in Canada (Baker 2002; Schirle 2008), in England (Banks, Blundell, and Casanova Rivas 2010; Schirle 2008), and in continental Europe (Honoré and de Paula 2015).

Certainly, some degree of retirement coordination between married

Nicole Maestas is associate professor of health care policy at Harvard Medical School and a research associate of the National Bureau of Economic Research.

This chapter was presented at the NBER Women Working Longer Conference, May 2122, 2016, Cambridge, MA. I thank my discussant Claudia Olivetti and the other conference participants for their valuable comments, and especially Claudia Goldin and Larry Katz for general guidance as well as detailed feedback. Cate Yoon and Kevin Friedman provided expert research. I gratefully acknowledge support from NIH/NIA grant no. R03AG023108 and the Alfred P. Sloan Foundation. For acknowledgments, sources of research support, and disclosure of the author's material financial relationships, if any, please see http://www.nber.org/chapters /c13799.ack.

1. The female-male difference in life expectancy conditional upon living to age sixty-five is about three years (Arias 2002), plus women are on average two to three years younger than their husbands, depending on birth cohort. 
partners is expected, if for no other reason than because husbands and wives share a budget set. For example, married women with greater wealth might individually choose to consume more leisure by retiring earlier, and so might their husbands, who share the same assets. Married couples may also have similar, or even directly linked, pension incentives (e.g., Social Security spousal benefits) that make possible retirement around the same time. Nonetheless, the dominant explanation for joint retirement may not even arise through the budget set, but through common preferences for joint leisure (Gustman and Steinmeier 2000, 2004; Maestas 2001; Michaud and Vermeulen 2011). In other words, spouses value each other's company and leisure complementarity leads them to retire around the same time.

Despite the utility benefits of joint leisure, the relatively younger retirement of married women may be costly for at least two reasons. First, with delayed or discontinuous labor force participation, married women may experience their peak earnings years just as they retire. Their husbands, on the other hand, may be past their peak earnings years, both on account of being older and having had relatively continuous labor force participation. As such, married women may forgo earnings opportunities that could both increase their Social Security benefit entitlements ${ }^{2}$ and increase private household net worth ${ }^{3}$ through additional saving. Second, married women tend to retire before age sixty-five, when they would be eligible for Medicare, and they therefore face the additional cost of purchasing health insurance from the time they retire until they turn sixty-five. Even those with employer-subsidized retiree health benefits may face significantly greater costs for health insurance before age sixty-five than after. Unless married couples compensate by increasing other assets, women's younger retirement may result in lower resources during the couples' remaining life together, and during any subsequent divorce or widowhood.

We know significantly less about the retirement behavior of women than we do about men, and virtually no research attention has been devoted to considering the implications of the fact that women retire at younger ages than men do. Even if married men fully compensate for the relatively younger retirement of their wives by working longer than they otherwise would, or if the Social Security benefit formulas fully compensate women through spousal and survivor benefits, married women may nevertheless forgo the opportunity to accrue significant pension assets in their own names. Theories of household decision making posit that asset and income ownership determines control over household consumption (see, e.g., Browning and Chiappori 1998; Lundberg and Pollak 1993; Maestas 2001). It is thus

2. See Gelber, Isen, and Song (chapter 8, this volume) for an analysis of the reverse pathway-how Social Security income affects women's labor supply at older ages.

3. See Lusardi and Mitchell (chapter 6, this volume) for an analysis of household net worth and women's labor supply. 
plausible that owning assets may give older women greater control over their allocation between the couple's joint lifetime and her expected years of survivorship.

I investigate the shape of the age-earnings profile for middle-aged and older married women to assess whether the return to continued work is larger for married women than for married men. Using the Health and Retirement Study (HRS), I document the changing patterns of employment at older ages among married women and married men, and establish the cross-spouse correlation in baseline work intentions and the likelihood of early retirement. I then estimate the shape of the age-earnings profile for married women, as compared to married men. Finally, I examine how continued work would affect the individual Social Security wealth of married women compared with married men, as well as the household-level Social Security wealth (which additionally accounts for the expected present value of spouse and survivor benefit entitlements).

Five key findings emerge from this study. First, preferences for joint leisure persist among married women and men in recent cohorts, suggesting that the trade-off between the potential return to continued work and preferences for joint leisure continues to be salient for couples. Second, married women in the boomer cohorts enter their fifties earning substantially more than their predecessors, and the growth across cohorts has been three times as great for married women than for married men. Third, estimates of the shapes of the age-earnings profiles indicate that the return to additional years of work is relatively larger for married women than for married men. Fourth, working until age seventy, that is, beyond the Social Security early and full retirement ages, would make a sizable increase in the magnitude of lifetime Social Security benefits to which married women are entitled. The gain in years worked at older ages would be sufficient to offset early gaps in their earnings records and would place women on par with men in terms of lifetime benefits. Finally, I find that individuals with the largest potential gains in Social Security wealth are just as likely to retire early as those with the least to gain. This suggests that individuals do not factor these potential gains into their employment decisions, and it raises the question of whether individuals are able to correctly assess the opportunity costs associated with reducing work effort before age seventy.

\subsection{Data and Summary Statistics}

\subsubsection{Data}

I use the 1992 to 2012 waves of the nationally representative Health and Retirement Study (HRS). ${ }^{4}$ The cohort structure of the HRS allows one

4. For additional details, see the volume appendix on the HRS. 
to compare cohorts at the same ages but across different years. I use the four birth cohort groups that enter the survey at ages fifty-one to fifty-six. The original HRS cohort (b. 1931 to 1941) entered the survey in 1992 at ages fifty-one to sixty-one, and has been observed in biennial interviews for twenty years. For age comparability with the other HRS cohorts, I use the younger members who were ages fifty-one to fifty-six in 1992 and label this group the HRS-Late cohort (b. 1936 to 1941). The War Babies cohort (b. 1942 to 1947) entered the survey in 1998 at ages fifty-one to fifty-six and has been observed for fourteen years. The Early Baby Boom (b. 1948 to 1953) entered at ages fifty-one to fifty-six in 2004 and has been observed for eight years, and the Mid-Baby Boom (b. 1954 to 1959) entered at ages fifty-one to fifty-six in 2010 and has been observed for two years. To increase statistical precision, I group the two "early cohorts" (HRS-Late and War Babies) and contrast them with the two "boomer cohorts" (Early Baby Boom and Mid-Baby Boom).

In the analyses that follow, I compare employment and earnings outcomes for married women and married men, by cohort. The HRS enrolls age-eligible respondents and their spouses. Some spouses are themselves age eligible for a cohort and are enrolled as primary respondents. As a result of this recruitment structure, in any contrast between married women and married men, most of the married women and men (though not all) are married to each other. I assign each respondent their marital status as of the baseline survey wave; that is, as of ages fifty-one to fifty-six. I use the RAND HRS Data, Version O (Chien et al. 2015).

\subsubsection{Summary Statistics: Demographics and Labor Supply at Baseline}

Table 2.1 presents cross-sectional summary statistics for married women and married men in the early cohorts compared to the boomer cohorts. As intended given the cohort structure of the analysis sample, the average age of respondents in each group is fifty-three years old. In line with national trends, the percent of married women with a college degree has risen substantially, from 19 percent in the early cohorts to 32 percent in the boomer cohorts. Among married men, the percent with a college degree has risen from 28 percent in the early cohorts to 35 percent in the boomer cohorts. Reflecting demographic trends in the US population, the boomer cohorts are more ethnically diverse than earlier cohorts. The boomer cohorts are slightly more likely to report "fair" or "poor" health than the earlier cohorts, particularly married men. Household wealth (measured as net worth) is substantially greater among the boomers compared to the early cohorts.

Table 2.1 also presents several measures of labor supply, all assessed at the baseline survey wave for each cohort (and therefore holding age constant). The employment rate of married women (at ages fifty-one to fifty-six) has risen from 64 percent in the early cohorts to 68 percent in the boomer cohorts. In contrast, the employment rate of married men (at the same ages) 


\begin{tabular}{|c|c|c|c|c|}
\hline & \multicolumn{2}{|c|}{ Early cohorts } & \multicolumn{2}{|c|}{ Boomer cohorts } \\
\hline & $\begin{array}{l}\text { Married } \\
\text { women } \\
(1)\end{array}$ & $\begin{array}{l}\text { Married } \\
\text { men } \\
(2)\end{array}$ & $\begin{array}{c}\text { Married } \\
\text { women } \\
\text { (3) }\end{array}$ & $\begin{array}{l}\text { Married } \\
\text { men } \\
(4)\end{array}$ \\
\hline Age at baseline & 53.4 & 53.4 & 53.5 & 53.5 \\
\hline College (\%) & 19.1 & 28.0 & 32.0 & 34.9 \\
\hline White non-Hispanic (\%) & 84.3 & 82.9 & 78.6 & 76.3 \\
\hline Hispanic $(\%)$ & 6.8 & 6.7 & 9.8 & 10.2 \\
\hline Black non-Hispanic (\%) & 6.7 & 7.3 & 7.1 & 8.3 \\
\hline Other race $(\%)$ & 2.2 & 3.0 & 4.4 & 5.2 \\
\hline Fair/poor health $(\%)$ & 17.2 & 16.5 & 18.6 & 19.4 \\
\hline Wealth (\$) & 477,807 & 415,877 & 517,085 & 509,055 \\
\hline Employed (\%) & 63.6 & 83.7 & 68.4 & 79.2 \\
\hline Lifetime number of years worked & 23.25 & 33.30 & 24.03 & 27.79 \\
\hline Earnings at baseline $(\$)^{\mathrm{a}}$ & 33,787 & 66,927 & 44,220 & 73,591 \\
\hline Wage at baseline $(\$ / \text { hour })^{\mathrm{a}}$ & 20.37 & 30.74 & 25.75 & 36.14 \\
\hline Weekly wage at baseline $(\$)^{\mathrm{a}}$ & 780 & 1,434 & 983 & 1,636 \\
\hline Hours worked per week ${ }^{\mathrm{a}}$ & 38.2 & 46.7 & 38.4 & 45.8 \\
\hline Weeks worked per year ${ }^{\mathrm{a}}$ & 49.4 & 50.6 & 48.8 & 50.3 \\
\hline Job tenure (years) ${ }^{\mathrm{a}}$ & 11.4 & 15.1 & 11.4 & 13.9 \\
\hline Number of observations & 3,385 & 3,169 & 2,793 & 2,677 \\
\hline
\end{tabular}

Source: Health and Retirement Study (HRS) 1992 to 2012, RAND HRS Version O.

Notes: Analysis sample contains married men and women who are age-eligible members of early cohorts (HRS-Late and War Babies) and boomer cohorts (Early Baby Boom and Mid-Baby Boom). Data are structured in cross-sectional format such that units of observation are person-level. All variables measured as of the baseline wave for each cohort. All dollar values reported in 2012 dollars. HRS respondent weights used.

${ }^{\text {a }}$ Statistic is conditioned on employment at baseline.

has declined across cohorts, from 84 to 79 percent. The lifetime number of years worked by married women (as of their early fifties) has risen from a mean of twenty-three years in the early cohorts to twenty-four years in the boomer cohorts. ${ }^{5}$ The lifetime number of years worked by married men is higher, but has declined by five years-from thirty-three years (early cohorts) to twenty-eight years (boomer cohorts). Baseline annual earnings (conditional on either full- or part-time employment and expressed in real 2012 dollars) are 31 percent higher among the boomer women $(\$ 44,220)$

5. The lifetime number of years worked was constructed by the RAND HRS from a series of questions recording respondents' self-reported labor force history (Chien et al. 2015). The slight increase in mean years of work masks pronounced changes at the tails of the distribution. Goldin and Katz (chapter 1, this volume, figures 1.7 and 1.8) show that the share of women in the labor force 80 to 100 percent of the time when they were ages twenty-five to fifty-four rose from 20 percent to more than 50 percent across cohorts, while the fraction in the labor force only 20 percent of the time or less declined. 
compared to married women in earlier cohorts $(\$ 33,787)$. This compares with cross-cohort growth in annual earnings of 10 percent among boomer men $(\$ 73,591)$ compared to married men in earlier cohorts $(\$ 66,927)$. The implied hourly wage grew by similar percentages across the cohort groups (26 percent for married women and 18 percent for married men), while hours worked per week and weeks worked per year were the same for both women and men. Thus, the earnings growth across cohorts appears to reflect a change in real wages for married women - perhaps as more of them have attained a college degree - and not simply growth in hours worked. Nor does it appear to reflect longer tenure in the job held at baseline. Mean job tenure for married women at baseline was 11.4 years in both the early and boomer cohorts. Mean job tenure among married men at the same ages fell by one year across cohorts - from fifteen years (early cohorts) to fourteen years (boomer cohorts).

\subsection{Employment Patterns of Married Women and Married Men}

\subsubsection{Cohort Comparisons of Employment by Age}

I next examine the full-time employment rate of married women by age and across cohorts, in comparison with married men. For this analysis, the underlying data are organized in longitudinal format, and the panel is unbalanced to create a semisynthetic age profile. A respondent first observed at age fifty-one contributes additional observations at fifty-three, fifty-five, and so forth. A respondent first observed at age fifty-two contributes additional observations at fifty-four, fifty-six, and so forth. The data for the Mid-Baby Boom cohort are largely cross-sectional since this cohort is only observed twice; the oldest member of the Mid-Baby Boom at baseline is only fiftyeight by their second interview in 2012 .

Figure 2.1 shows that the full-time employment rate among married women in the boomer cohorts is higher than in the earlier cohorts at every age (from fifty-one to sixty-four). ${ }^{6}$ The full-time employment rate for married men is higher than for women at all ages, but in contrast, the married men in the boomer cohorts are less likely to be employed full time than men in the early cohorts until about age fifty-eight - this pattern is driven by the Mid-Baby Boom cohort who experienced weaker employment conditions in the aftermath of the Great Recession than did earlier cohorts at those ages.

Figure 2.2 shows the age profiles in part-time employment. Among married women, the age profile in part-time employment is relatively flat with age (in the neighborhood of 20 percent) and perhaps somewhat higher among

6. Full-time work is defined as working at least thirty-five hours per week for at least thirtysix weeks per year. Part-time work is defined as working less than thirty-five hours per week or less than thirty-six weeks per year. 


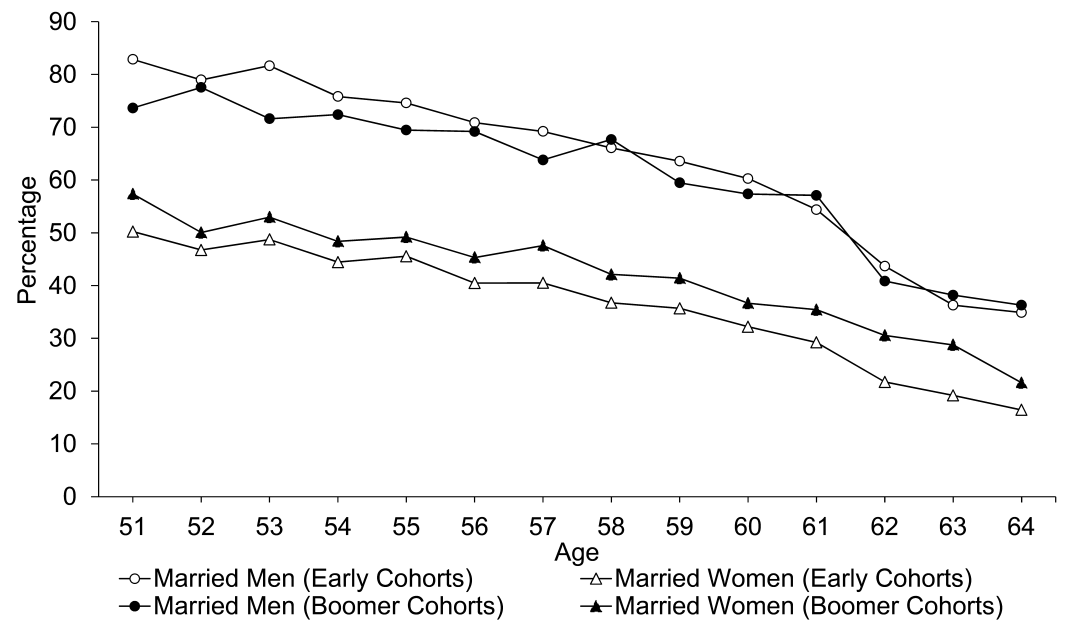

Fig. 2.1 Percent working full time by age

Source: Health and Retirement Study (HRS) 1992 to 2012, RAND HRS Version O.

Notes: Data are structured in (unbalanced) panel format such that units of observation are person-wave. Early cohorts are HRS-Late and War Babies. Boomer cohorts are Early Baby Boom and Mid-Baby Boom. Full-time work is defined as working at least thirty-five hours per week for at least thirty-six weeks per year. The hours and weeks from both the main and any second job are counted when determining whether the respondent is working full time.

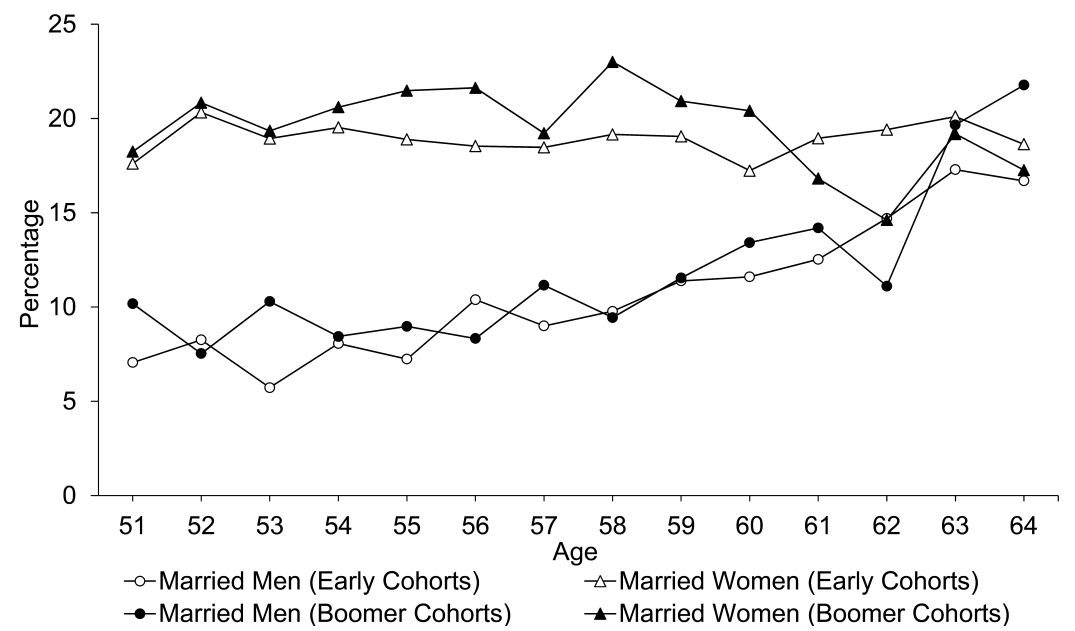

Fig. 2.2 Percent working part time by age

Source: Health and Retirement Study (HRS) 1992 to 2012, RAND HRS Version O.

Notes: Data are structured in (unbalanced) panel format such that units of observation are person-wave. Early cohorts are HRS-Late and War Babies. Boomer cohorts are Early Baby Boom and Mid-Baby Boom. Part-time work is defined as either working less than thirty-five hours per week or less than thirty-six weeks per year. The hours and weeks from both the main and any second job are counted when determining whether the respondent is working part time. 
boomer women in their late fifties. In contrast, part-time employment among married men rises with age, so that by their midsixties, the part-time employment rate is similar for married men and women.

\subsubsection{Labor Supply Correlations across Spouses}

In table 2.2, I document the labor supply patterns of couples. As noted earlier, most respondents in the columns for married women are married to the men in the adjacent column for married men; however, the correspondence is not complete, which accounts for the modest differences in statistics measured at the couple level. Table 2.2 shows that in about one-half of couples, both spouses were employed at baseline. Perhaps surprisingly, this statistic is only slightly higher among the boomer cohorts (married women subsample). The husband-wife age difference has declined across cohorts, falling from 2.7 years among married women in the earlier cohorts to 2.0 years in the boomer cohorts. Correspondingly, while 69 percent of married women were married to older men in the early cohorts, somewhat fewer-63 percent - are married to older men in the boomer cohorts.

In the HRS, respondents are asked about their future employment expectations. Specifically, they are asked to state the chance they will work full time after age sixty-two and age sixty-five. Among married women, the mean stated chance of working full time after sixty-five has risen from 18 percent to 25 percent across cohorts. Men, too, increasingly expect to work full time after sixty-five, with the mean stated chance rising from 30 percent to 36 percent across cohorts.

I next use the longitudinal information in the HRS to measure observed transitions to early retirement, specifically the percent reducing work effort within eight years of their baseline interview (ages fifty-one to fifty-six). A reduction in work effort is defined as (a) a transition from full-time work to either part-time work or no work, or (b) a transition from part-time work to no work. Table 2.2 shows that 51 percent of married women in the early cohorts retired early compared with 47 percent among the boomer cohorts. Notably, married men are less likely to retire early than married women-43 percent in the early cohorts compared with 41 percent in the boomer cohorts. Rates of reentry, here defined as increasing work effort within two years of reducing effort, are similar for married women in the early and boomer cohorts ( 25 percent and 23 percent, respectively), but have fallen for married men across cohorts (from 28 percent to 21 percent).

Finally, table 2.2 shows that early retirement is somewhat more likely among women whose husbands themselves expressed (at baseline) a belowaverage chance of working full time after sixty-five. ${ }^{7}$ Among these women, 52 percent in the early cohorts retired early compared with 48 percent of early cohort women whose husbands expressed an above-average chance of

7. A "below-average" stated probability of working full time after age sixty-five is a stated chance less than the married sample mean of 28 percent. 
Reductions in work effort among couples

\begin{tabular}{|c|c|c|c|c|}
\hline & \multicolumn{2}{|c|}{ Early cohorts } & \multicolumn{2}{|c|}{ Boomer cohorts } \\
\hline & $\begin{array}{l}\text { Married } \\
\text { women } \\
\text { (1) }\end{array}$ & $\begin{array}{l}\text { Married } \\
\text { men } \\
(2)\end{array}$ & $\begin{array}{l}\text { Married } \\
\text { women } \\
\text { (3) }\end{array}$ & $\begin{array}{c}\text { Married } \\
\text { men } \\
(4)\end{array}$ \\
\hline $\begin{array}{l}\text { Both spouses employed at baseline } \\
(\%)\end{array}$ & 45.7 & 52.9 & 48.5 & 51.5 \\
\hline $\begin{array}{l}\text { Husband-wife age difference } \\
\text { (years) }\end{array}$ & 2.7 & 3.4 & 2.0 & 2.6 \\
\hline Husband older $(\%)$ & 69.2 & 73.7 & 62.9 & 66.4 \\
\hline $\begin{array}{l}\text { Stated chance of working FT after } \\
\text { sixty-five }(\%)\end{array}$ & 17.8 & 29.6 & 25.2 & 36.1 \\
\hline $\begin{array}{l}\text { Reduction in work effort w/in eight } \\
\text { years }(\%)\end{array}$ & 51.0 & 42.9 & 46.7 & 41.0 \\
\hline $\begin{array}{l}\text { Increase in work effort w/in two } \\
\text { years of reduction }(\%)\end{array}$ & 25.0 & 27.7 & 22.9 & 20.9 \\
\hline $\begin{array}{l}\text { Reduction in work effort w/in eight } \\
\text { years | spouse does not plan to } \\
\text { work longer }(\%)\end{array}$ & 52.3 & 44.1 & 47.7 & 41.6 \\
\hline $\begin{array}{l}\text { Reduction in work effort w/in eight } \\
\text { years | spouse plans to work } \\
\text { longer }(\%)\end{array}$ & 47.6 & 37.1 & 44.5 & 39.0 \\
\hline Number of observations & 3,385 & 3,169 & 2,793 & 2,677 \\
\hline
\end{tabular}

Source: Health and Retirement Study (HRS) 1992 to 2012, RAND HRS Version O.

Notes: Analysis sample contains married men and women who are age-eligible members of early cohorts (HRS-Late and War Babies) and boomer cohorts (Early Baby Boom and MidBaby Boom). Data are structured in cross-sectional format such that units of observation are person-level. All variables measured as of the baseline wave for each cohort. Variable "spouse does not plan to work longer" is an indicator for stated chance of working full-time after age sixty-five being less than its mean value of 28 percent, while "spouse plans to work longer" is the complement. HRS respondent weights used.

working full time after sixty-five. This difference by husbands' expectation is smaller among boomer women, suggesting that women in later cohorts may be less influenced by their husbands' retirement expectations. Men, too, are more likely to retire early when their wives held a below-average baseline expectation of working full time after sixty-five than when their wives held an above-average expectation; that said, men in general appear somewhat less likely than women to be influenced by their spouse's retirement expectation.

\subsection{The Return to Continued Work for Married Women}

The relative rise in full-time employment among older married women compared with men in figures 2.1 and 2.2 indicates greater labor force attachment among more recent cohorts of older married women. One candidate 
explanation for this pattern is that the return to additional years of work has risen for married women relative to married men. The return to additional work has at least two key components: the additional earnings earned and the incremental gain in future Social Security benefit payments (also known as Social Security wealth) ${ }^{8}$

The first piece of evidence in support of the hypothesis of a rising return to additional work came from table 2.1, where we saw that boomer women enter their early fifties earning substantially more ( 31 percent) than women in earlier cohorts, and that this growth in earnings has outpaced crosscohort growth in earnings for men (10 percent). In this section, I examine the subsequent trajectory of earnings from ages fifty-one to sixty-four for married women compared with married men to test if there are material differences in the slopes of the age-earnings profiles. I then turn to an analysis of Social Security wealth to investigate whether there are differential gains in Social Security wealth from additional years of earnings for married women relative to men.

\subsubsection{Age-Earnings Profiles}

The age-earnings profiles for married women and men in each cohort group are shown in figure 2.3. Earnings are in 2012 dollars, top coded at $\$ 250,000$ to address extreme values, and exclude those with zero earnings. The age-earnings profile for married women is flat from age fifty-one until their early sixties, and is considerably higher for boomer women than for women in earlier cohorts. In contrast, the age-earnings profile for married men visibly declines with age in both cohort groups. This decline in real earnings for men - reflecting stagnant earnings growth as well as a rising incidence of part-time work - results in a marked narrowing of the malefemale earnings gap by the early sixties.

To extract a clearer picture of the relative changes for married women and men, I next estimate the slopes of the female and male age-earnings profiles. Table 2.3 presents coefficients from ordinary least squares (OLS) regressions of real earnings (conditional on employment) on a quadratic function of age, estimated separately for married women and married men in each cohort group, and using the data in longitudinal format (personwave) as described above. To account for selection into continued employment on the basis of labor force attachment and prior earnings, I include controls for baseline earnings, baseline hours worked per year, baseline weeks worked per year, tenure in the baseline job, lifetime number of years worked as of baseline, and a series of indicators for groups of three-digit

8. Another potential component is the incremental gain in lifetime pension benefits for those with an employer-sponsored pension plan, offset by the forgone value of the annual pension benefit if the individual could have collected pension benefits in the year in question (see Maestas [2001] for a model of the return to additional work). 


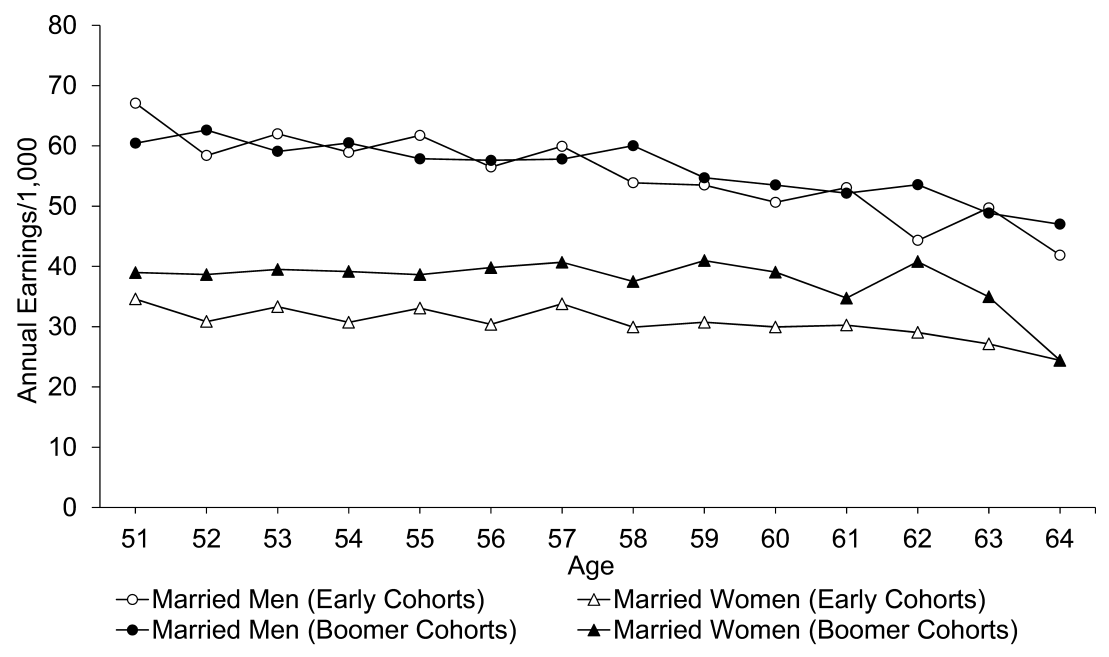

Fig. 2.3 Earnings of all workers by age

Source: Health and Retirement Study (HRS) 1992 to 2012, RAND HRS Version O.

Notes: Data are structured in (unbalanced) panel format such that units of observation are person-wave. Earnings are conditional on employment. All dollar values reported in 2012 dollars. Early cohorts are HRS-Late and War Babies. Boomer cohorts are Early Baby Boom and Mid-Baby Boom.

occupations. ${ }^{9}$ Also included are indicators of college degree status, race and ethnicity, self-reported fair or poor health status (measured at baseline), household wealth quintile (measured at baseline), and HRS cohort designation. The coefficients on the quadratic age function indicate that each additional year of age is associated with a relative gain in real earnings for married women compared with married men. Since the shape of the age profile is difficult to infer from the coefficients alone, figure 2.4 plots predicted earnings by age relative to predicted earnings at age fifty-one, using the age coefficients from table 2.3. Panel A of figure 2.4 shows the ageearnings profile for married men and married women in the early cohorts, while panel B shows the profiles for the boomer cohorts. In both cohort groups, women's real earnings rise slightly until age fifty-five, stabilize, and then trend downward after age fifty-seven. In contrast, real earnings for

9. The groups of three-digit occupations are based on the 1980 census classification as follows: managerial specialty operation (003-037); professional specialty operation and technical support (043-235); sales (243-285); clerical, administrative support (303-389); service: private household, cleaning and building services (403-407); service: protection (413-427); service: food preparation (433-444); health services (445-447); personal services (448-469); farming, forestry, fishing (473-499); mechanics and repair (503-549); construction trade and extractors (553-617); precision production (633-699); operators: machine (703-799); operators: transport, etc. (803-859); operators: handlers, etc. (863-889); and member of armed forces (900). 


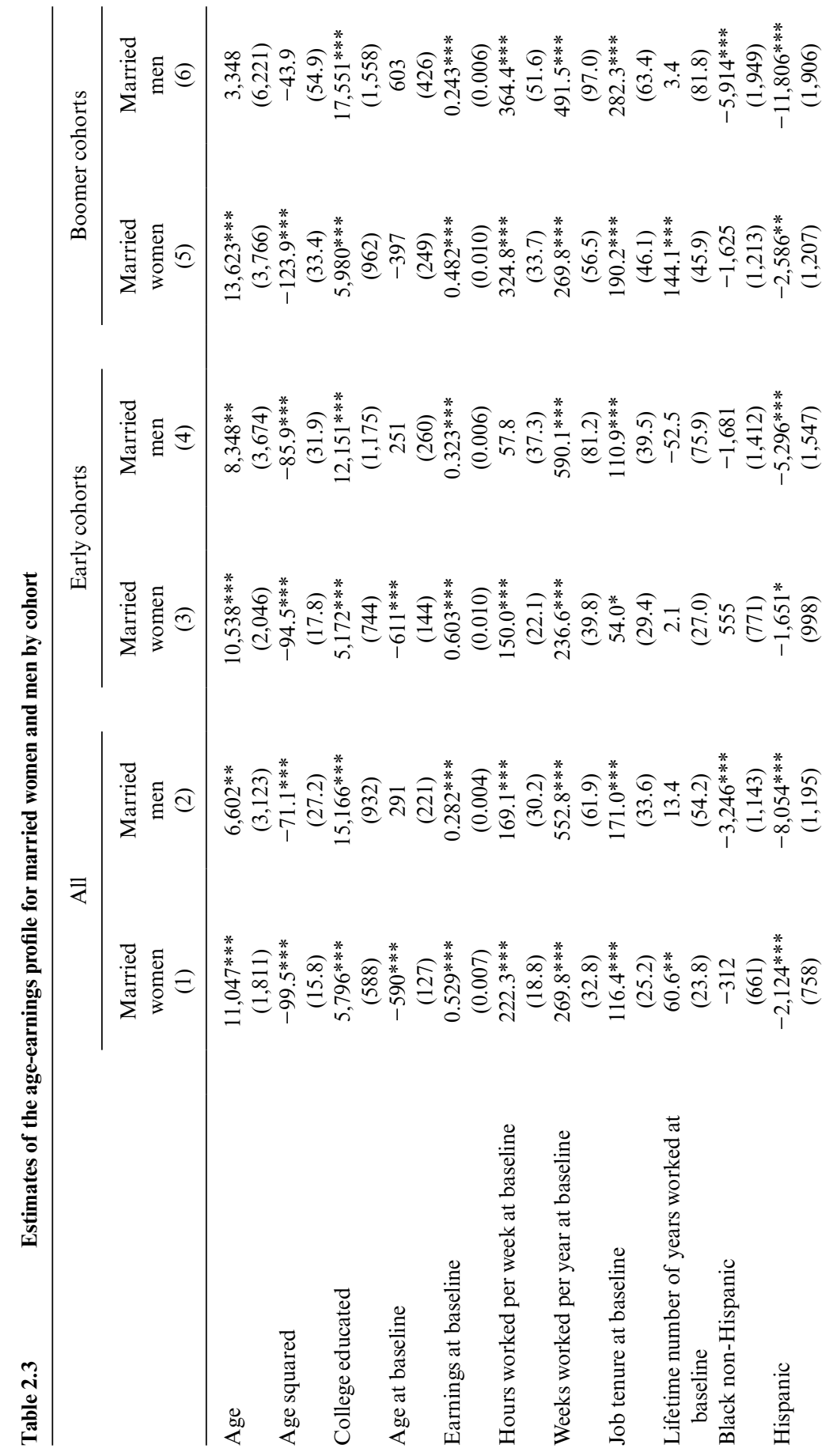




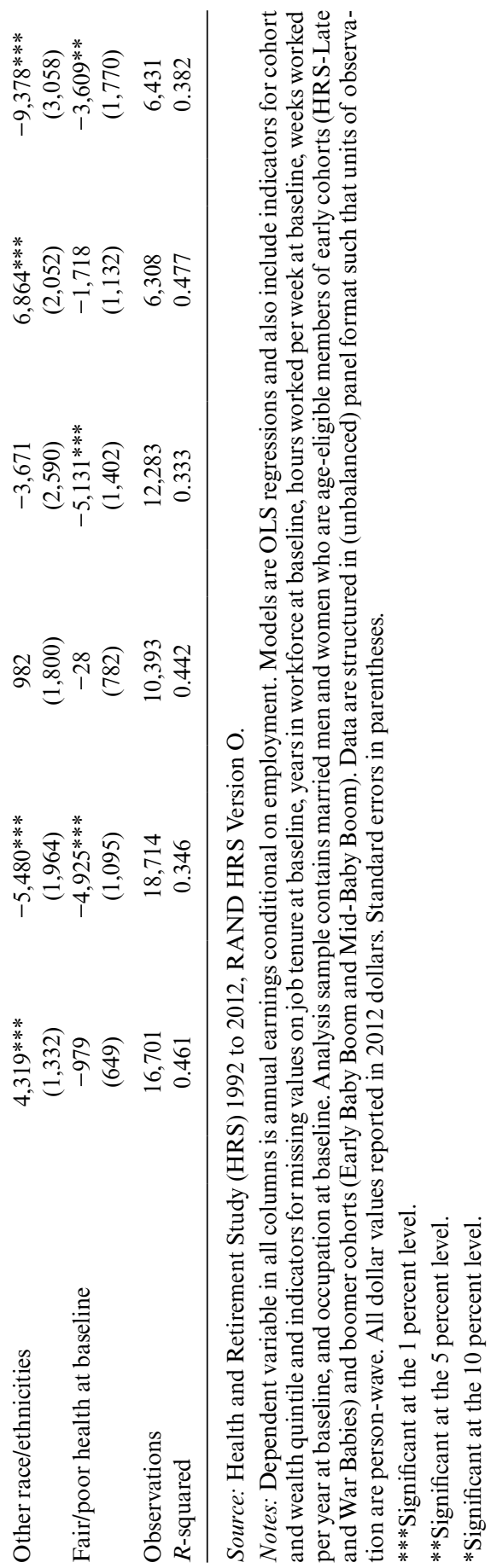

You are reading copyrighted material published by University of Chicago Press. Unauthorized posting, copying, or distributing of this work except as permitted under U.S. copyright law is illegal and injures the author and publisher. 
A. Early Cohorts

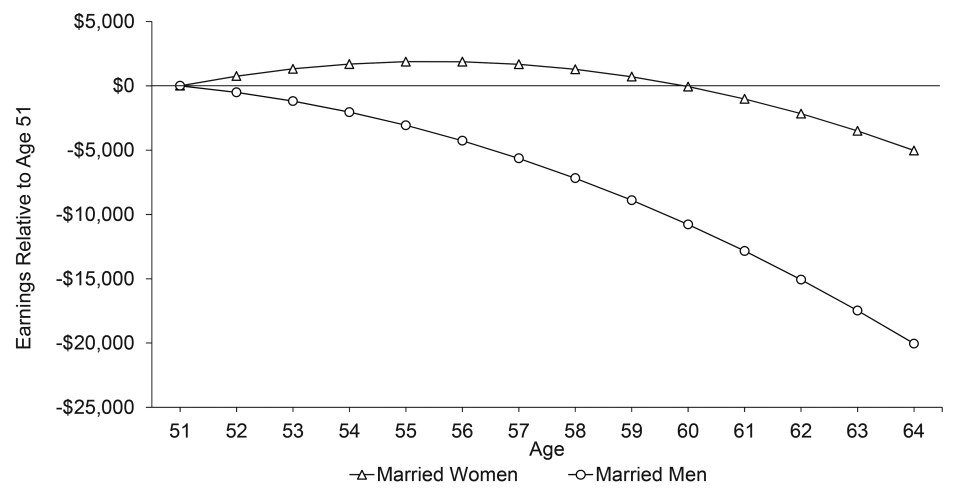

B. Boomer Cohorts

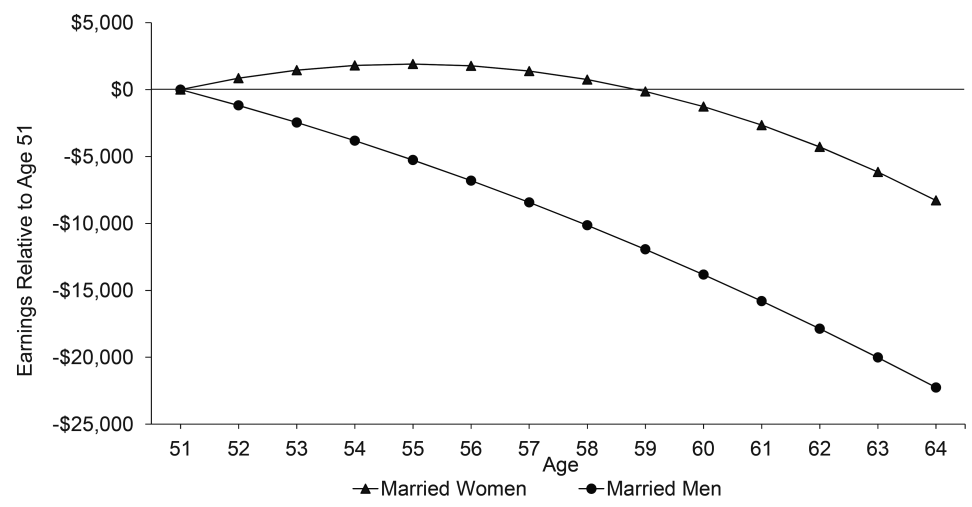

Fig. 2.4 Predicted annual earnings by age, relative to earnings at age fifty-one Source: Health and Retirement Study (HRS) 1992 to 2012, RAND HRS Version O.

Notes: Data values are predicted earnings by age using the age and age squared coefficients from table 2.3. Data are structured in (unbalanced) panel format such that units of observation are person-wave. Earnings are conditional on employment. All dollar values reported in 2012 dollars. Early cohorts are HRS-Late and War Babies. Boomer cohorts are Early Baby Boom and Mid-Baby Boom.

men decline annually from ages fifty-one to sixty-one. As a result, at every age the return to continued work for women is greater than it is for men, and grows until at least age sixty-four. ${ }^{10}$

I next investigate whether the changes in annual earnings with age in figure 2.4 appear to correspond with changes in extensive margin labor supply, or changes in the real wage rate. Table 2.4 presents estimates from sepa-

10. The age-earnings profile for divorced and separated women (not shown) is similar to that of married women in both cohorts. See Olivetti and Rotz (chapter 4, this volume) for an analysis of divorce risk and labor supply. 


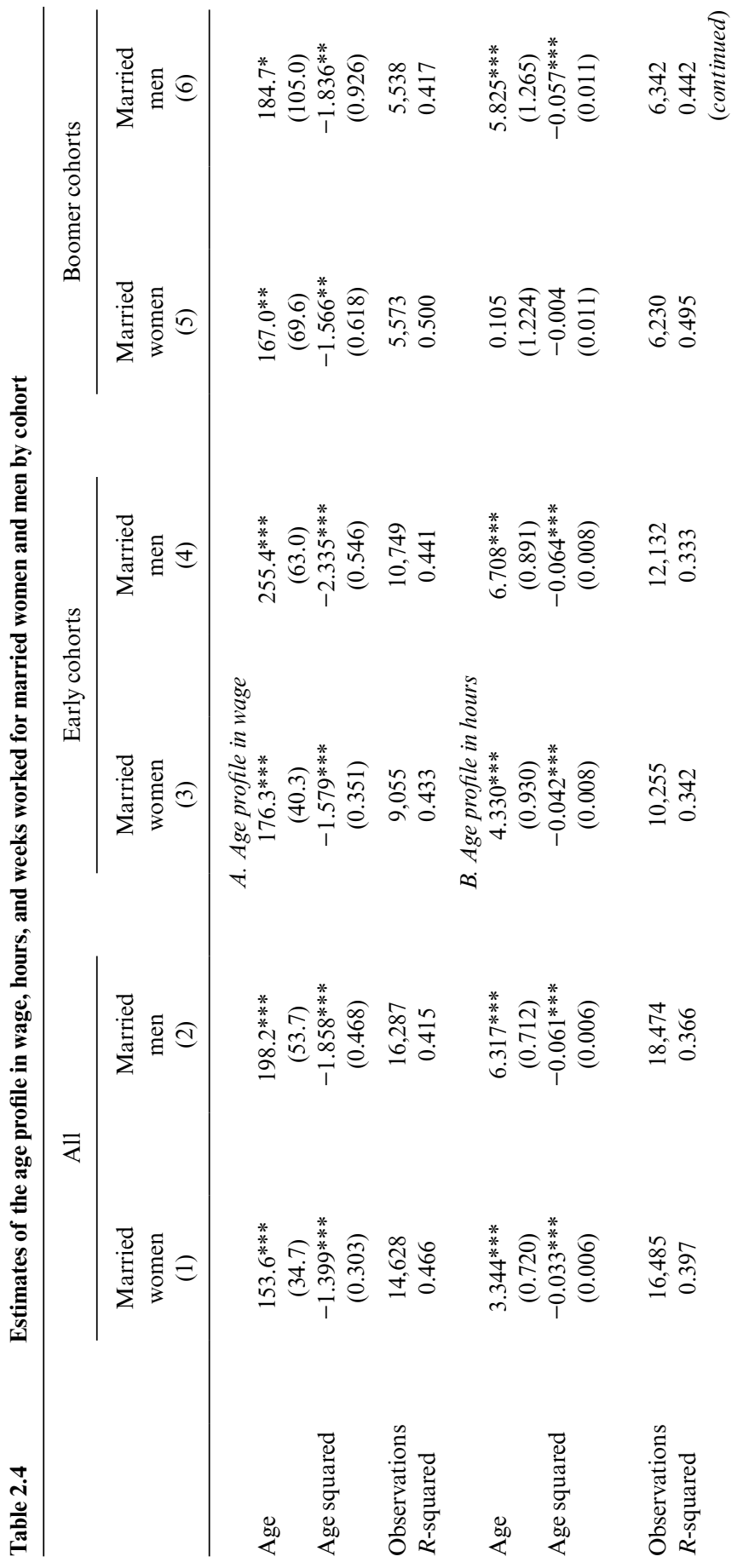




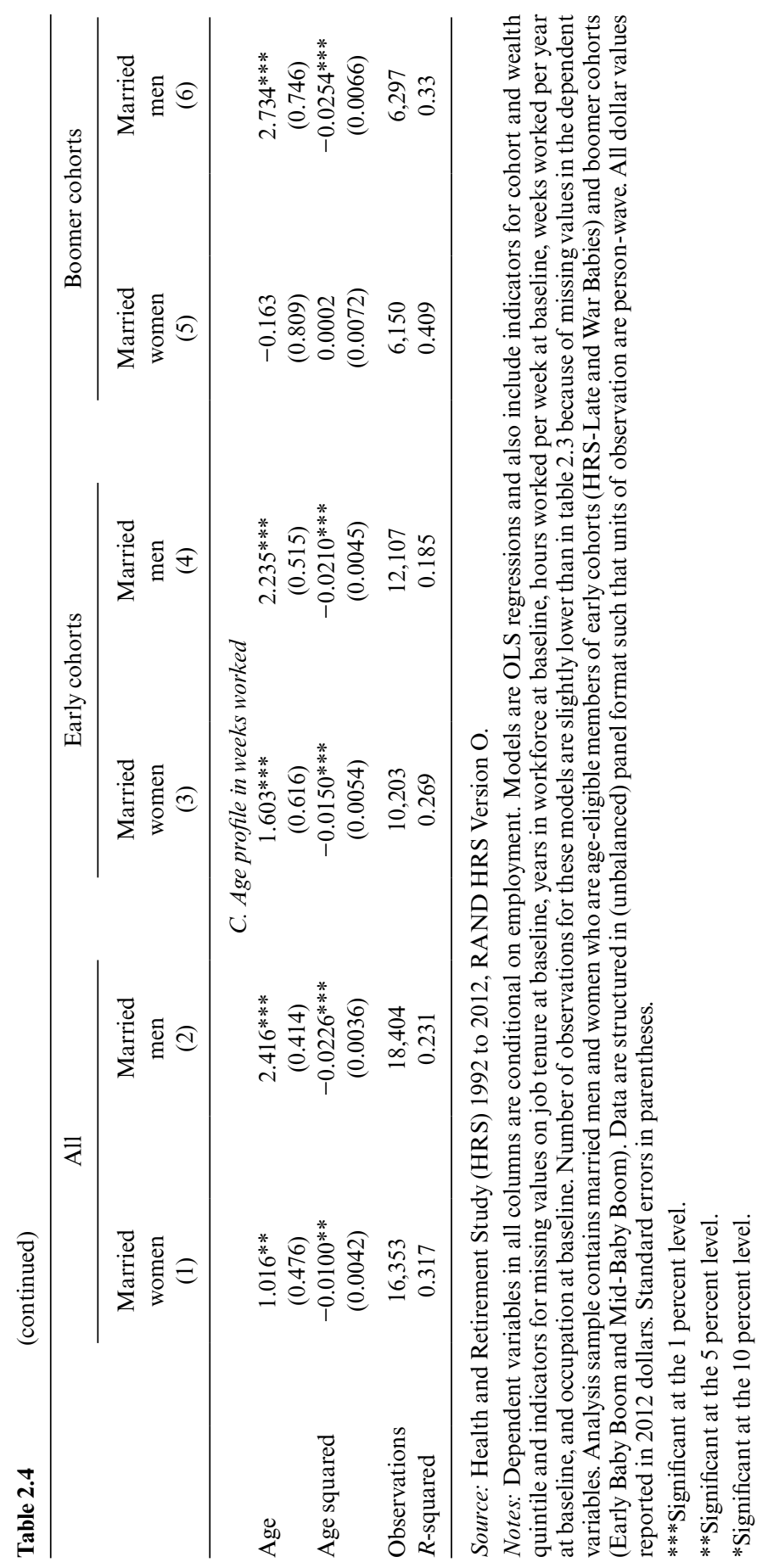


A. Early Cohorts

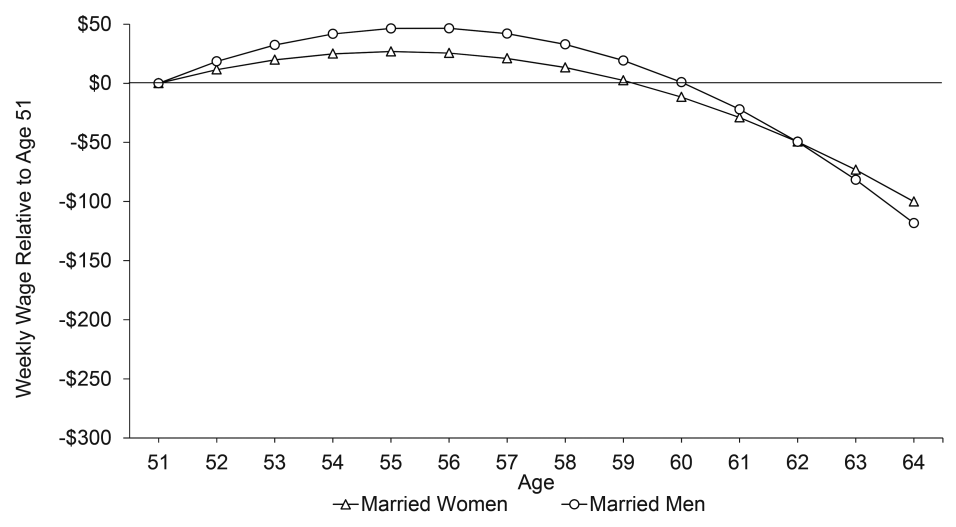

B. Boomer Cohorts

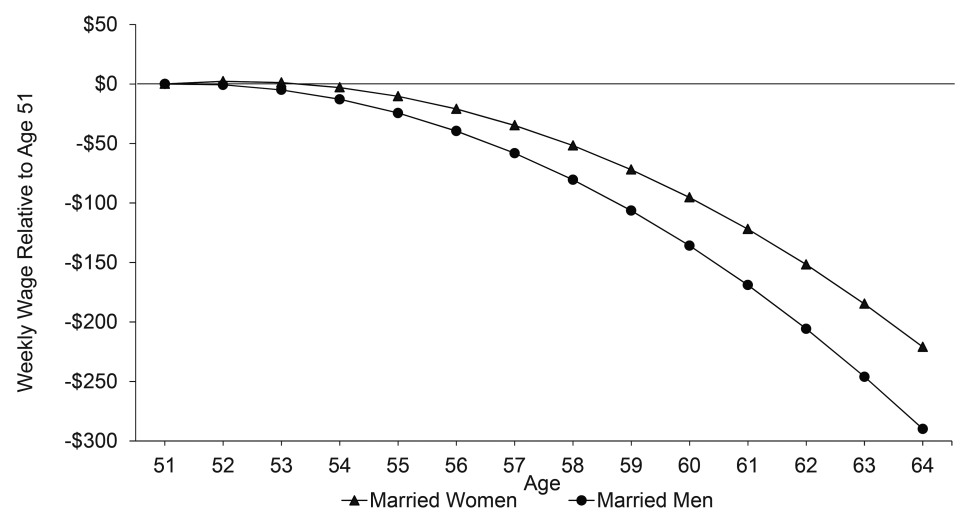

Fig. 2.5 Predicted weekly wage by age, relative to wage at age fifty-one

Source: Health and Retirement Study (HRS) 1992 to 2012, RAND HRS Version O.

Notes: Data values are predicted weekly wage by age using the age and age squared coefficients from table 2.4. Data are structured in (unbalanced) panel format such that units of observation are person-wave. Weekly wage is conditional on employment. All dollar values reported in 2012 dollars. Early cohorts are HRS-Late and War Babies. Boomer cohorts are Early Baby Boom and Mid-Baby Boom.

rate models of the age-wage (panel A), age-hours (panel B), and age-weeks (panel C) profiles, each estimated using the specification in table 2.3. Figure 2.5 plots the predicted weekly wage by age (relative to the weekly wage at age fifty-one). For married women in both cohorts, the age profile in the weekly wage largely tracks the age profile in earnings (although it is somewhat flatter for boomer women in their early fifties). The pattern for married men is more nuanced. Among men in the early cohorts, the weekly wage rises modestly 
A. Early Cohorts

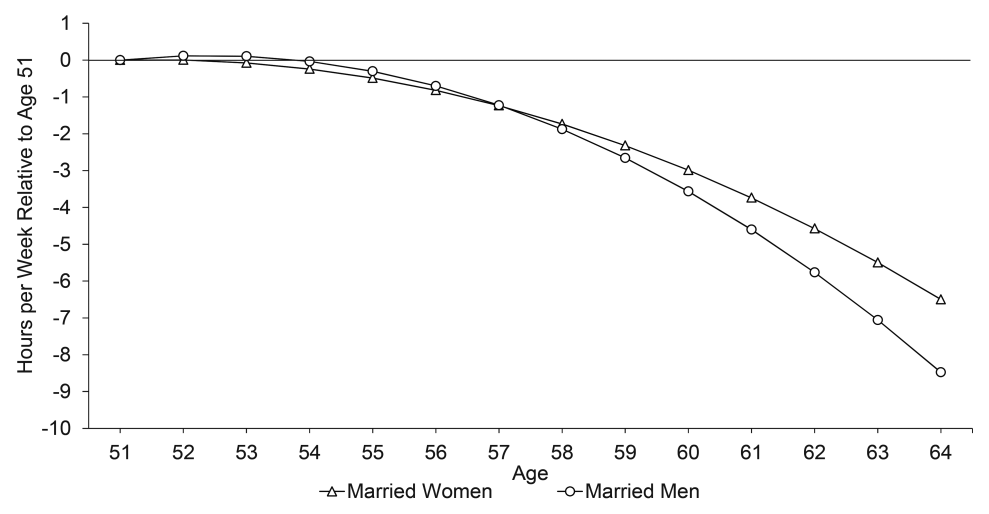

B. Boomer Cohorts

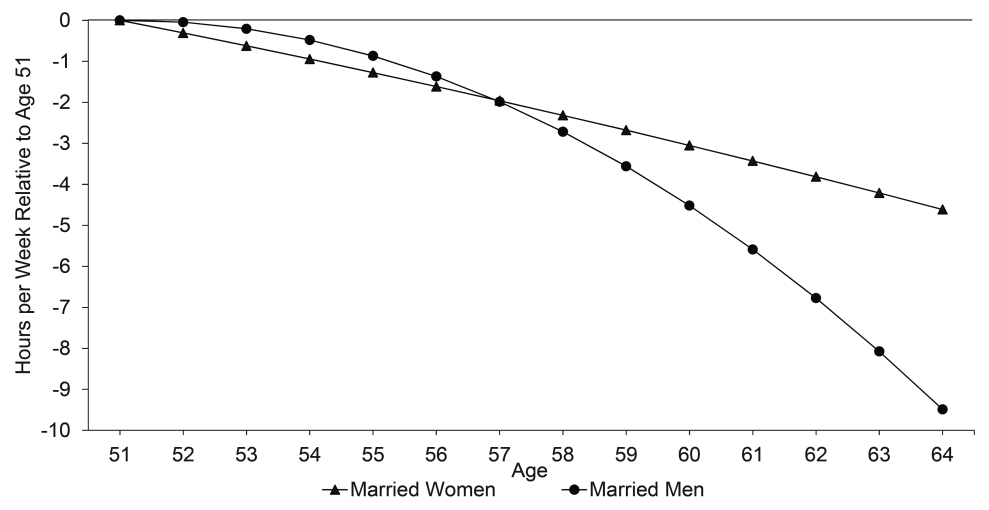

Fig. 2.6 Predicted hours per week by age, relative to hours at age fifty-one Source: Health and Retirement Study (HRS) 1992 to 2012, RAND HRS Version O.

Notes: Data values are predicted hours per week by age using the age and age squared coefficients from table 2.4. Data are structured in (unbalanced) panel format such that units of observation are person-wave. Hours per week are conditional on employment. All dollar values reported in 2012 dollars. Early cohorts are HRS-Late and War Babies. Boomer cohorts are Early Baby Boom and Mid-Baby Boom.

until their midfifties, when it begins to decline. The declining age-earnings profile for early cohort men in their early fifties, it appears, may have been driven by changes in extensive margin labor supply. Among boomer men, the weekly wage declines in tandem with earnings.

Figures 2.6 and 2.7 show the measures of extensive margin labor supply, predicted hours worked per week and predicted weeks worked per year, respectively. These figures indicate that among men in both cohorts, the 
A. Early Cohorts

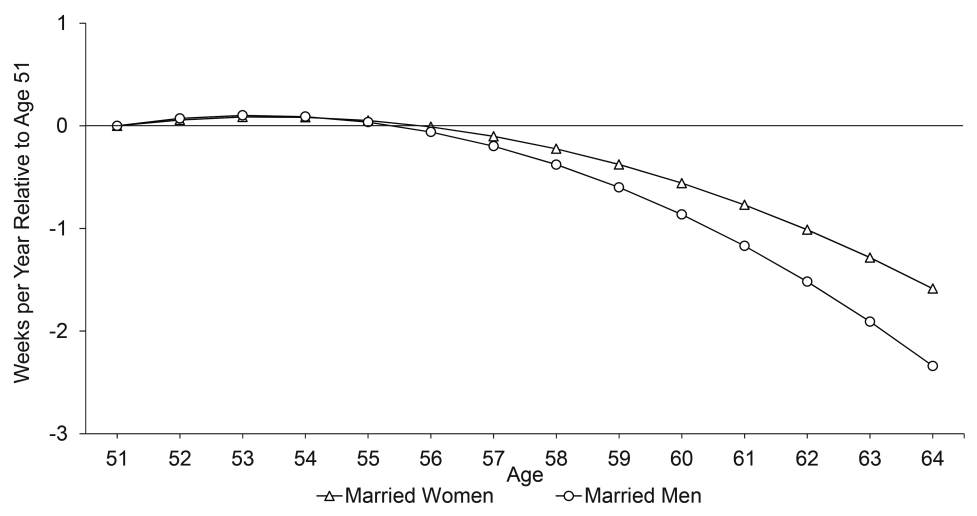

B. Boomer Cohorts

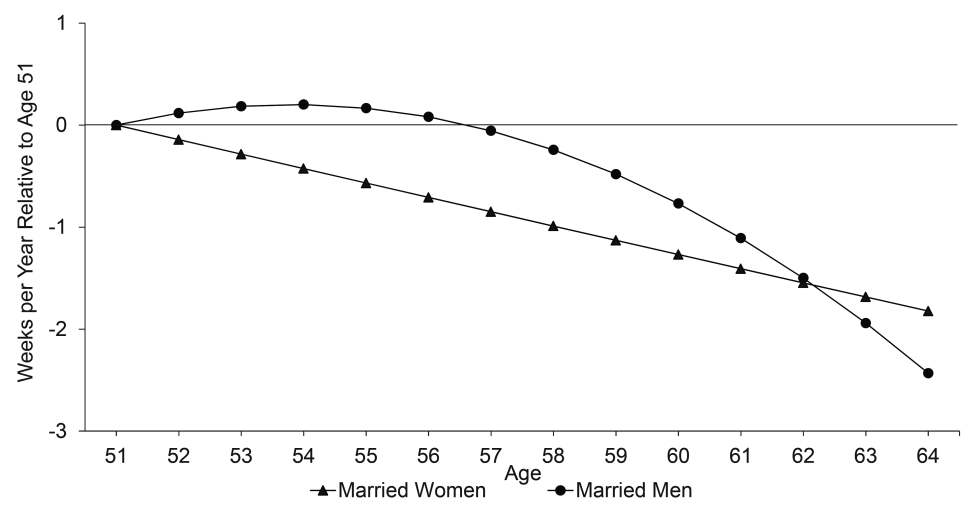

Fig. 2.7 Predicted weeks worked per year by age, relative to weeks worked at age fifty-one

Source: Health and Retirement Study (HRS) 1992 to 2012, RAND HRS Version O.

Notes: Data values are predicted weeks worked per year by age using the age and age squared coefficients from table 2.4. Data are structured in (unbalanced) panel format such that units of observation are person-wave. Weeks worked is conditional on employment. All dollar values reported in 2012 dollars. Early cohorts are HRS-Late and War Babies. Boomer cohorts are Early Baby Boom and Mid-Baby Boom.

decline in the earnings profile in their early fifties coincides with modest reductions in hours per week, while weeks worked are stable. For women, hours per week and weeks worked per year are either flat or trending downward beginning in their early fifties. Thus, it does not appear married women are achieving their stable earnings profile by compensating for real losses in earnings with increases in extensive margin labor supply. 


\subsubsection{Social Security Wealth}

The earnings patterns documented thus far indicate that lifetime earnings for married women have risen across cohorts, both absolutely and relative to the earnings of men, thus resulting in a narrowing of the gender gap in earnings with age. The gain in lifetime earnings for married women has important implications for women's retirement security, particularly considering the risks of divorce and widowhood. In this section, I first examine the effects of continued work on individual Social Security wealth. I then turn to the relative contributions of continued work by women and men to the Social Security wealth of the household, accounting for the value of spouse and survivor benefits. Finally, I investigate whether it is the case that individuals with larger potential gains from delaying retirement and claiming are more likely to work longer.

\section{Individual Social Security Wealth}

Social Security retirement benefits are primarily determined by average earnings over a thirty-five-year period. As cultural norms once dictated married women should not engage in labor market activity while raising children, married women have typically accrued many more years of "zero" earnings than married men, resulting in low average lifetime earnings and, correspondingly low Social Security retirement benefits. But as married women in recent cohorts have accrued more years of work, along with higher annual earnings, their Social Security benefit entitlements should have also risen.

Figure 2.8 shows that this is indeed the case. The figure shows predicted Social Security wealth (SSW) for married women and married men in each cohort group, by potential claiming age. Social Security wealth is the expected present value of future Social Security retirement benefits based on the respondent's actual earnings history until their baseline survey wave, and assuming continued work at the same earnings until the target claiming age. Social Security wealth is computed by applying Social Security's benefit computation calculator (ANYPIA) ${ }^{11}$ to the restricted Social Security earnings records of HRS respondents (Kapinos et al. 2016). The calculator applies all aspects of the benefit calculation formula, including adjustments for early and delayed retirement. Social Security wealth is included in the publicly available RAND HRS files. For each respondent, SSW is calculated for three potential claiming ages - the early retirement age (age sixty-two), the full retirement age (age sixty-five or sixty-six depending on birth cohort), and age seventy (the maximum benefit initiation age). For all three potential claiming ages, actual earnings are measured until the baseline survey wave,

11. The ANYPIA Social Security benefit calculator can be downloaded from https://www .ssa.gov/oact/anypia/download.html. 


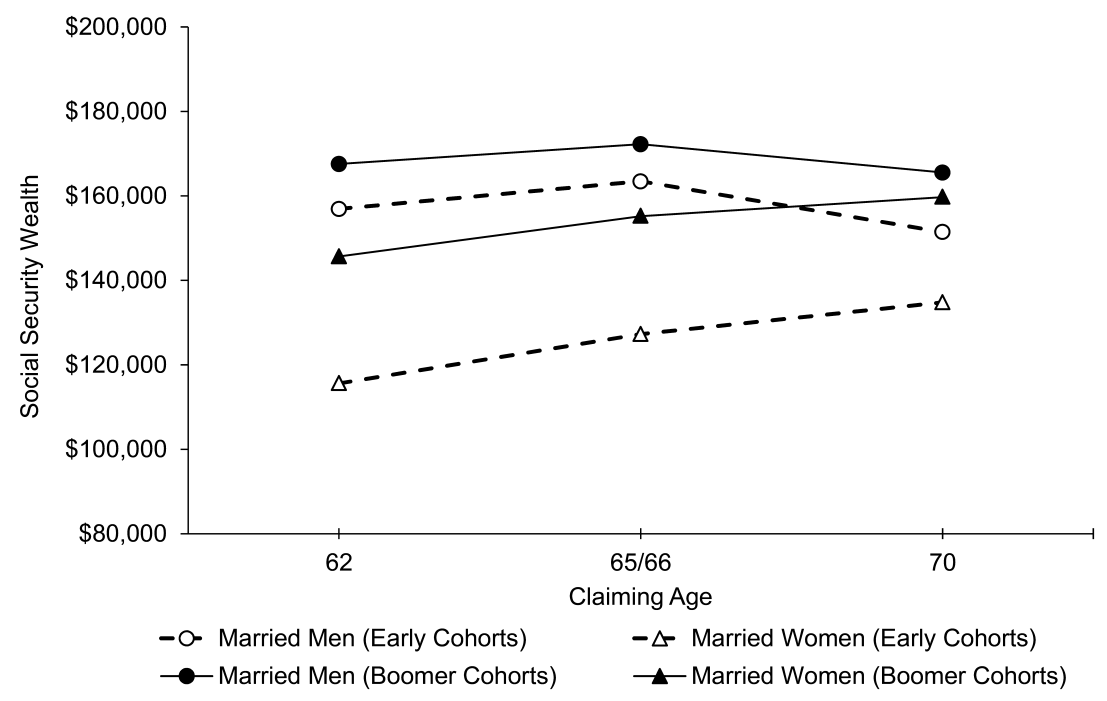

Fig. 2.8 Potential Social Security wealth if continue working until claiming age Source: Health and Retirement Study (HRS) 1992 to 2012, RAND HRS Version O.

Notes: Data are structured in cross-sectional format such that units of observation are personlevel. Social Security wealth (SSW) is the expected present discounted value of potential Social Security benefits earned on the respondent's own record if the respondent continued to work until the indicated claiming age. (For methodological details, see Kapinos et al. [2016] and Chien [2015].) Claiming age "65/66" pools respondents who have a full retirement age of either sixty-five or sixty-six. Early cohorts are HRS-Late and War Babies. Boomer cohorts are Early Baby Boom and Mid-Baby Boom. All dollar values reported in 2012 dollars. HRS respondent weights used.

and then projected forward to the indicated claiming age. ${ }^{12}$ The projection uses a moving average of the last five years of earnings (unequally weighted), and effectively assumes a flat profile in real earnings beyond the baseline wave.

Figure 2.8 shows that at every claiming age, married women in the boomer cohorts (the solid line) have substantially greater individual SSW than women in the earlier cohorts (dotted line). For instance, mean SSW at age sixty-two among married women in the boomer cohorts is $\$ 145,644$ compared with $\$ 115,609$ in the early cohorts - an increase of 26 percent. Social Security wealth at age sixty-two is also higher among boomer men $(\$ 167,558)$ than early cohort men $(\$ 156,928)$, but by proportionately less (7 percent). Note that the underlying data are at the respondent level (as

12. This measure only includes own benefit entitlements based on the respondent's own earnings history. It does not include the present value of any spouse benefits that would be paid based on the respondent's earnings record to either a current, past, or surviving spouse. For methodological details, see Kapinos et al. (2016). 
opposed to respondent-wave level in the age-earnings analyses), and since predicted SSW can be computed for all three potential claiming ages if it can be computed for one, the age profiles in SSW in figure 2.8 are a balanced panel. ${ }^{13}$

Figure 2.8 also reveals a related important finding: if married women continued working at the same annual earnings rate between ages sixty-two and seventy, their Social Security wealth would rise by a substantial amount -17 percent among early cohort women and 10 percent among boomer women (the absolute gain is larger for boomer women, but they have a higher base level at sixty-two, resulting in a smaller percent change). In striking contrast, mean predicted Social Security wealth declines slightly for men in both the early and boomer cohorts (by -3 percent and -1 percent, respectively).

Thus, whereas additional years of work after age sixty-two do not increase Social Security wealth for married men (even at constant real earnings), additional years of work make a measurable increase in the SSW of married women. ${ }^{14}$ The reason is because the marginal earnings replace earlier years of lower (or zero) earnings in the benefit computation formula for women, but not for men. In fact, this is the only channel by which SSW can increase in figure 2.8. The increase in potential SSW is not due to the effect of delayed claiming, or to the more favorable survival probabilities for women. ${ }^{15}$ Table 2.5 presents estimates of the relative gain for married women in an OLS regression with married women and men pooled, and including the same control variables as in table 2.3. The relative within-individual gain from ages sixty-two to seventy for married women compared to men is a statistically significant $\$ 22,547$ in the early cohorts and $\$ 20,202$ for the boomer cohorts.

Overall, the gender gap in individual SSW would narrow to such a degree across cohorts that continued work to age seventy would place married women on near equal footing with married men, at least in terms of SSW. The equivalence might seem surprising given married women earn less on

13. In instances where respondents did not consent to release their Social Security earnings records, HRS used imputation methods to construct the primary insurance amount (PIA) on which SSW is based. Some 19 to 27 percent of respondents, depending on their baseline wave, received some form of PIA imputation for this reason. A number of respondents did not consent at their first interview but did so at a later interview, which ultimately reduced the number of respondents with missing earnings records. See Kapinos et al. (2016) for details.

14. The same is also true for divorced and separated women.

15. Recall that the actuarial adjustments in the benefit amount for early (age sixty-two) and delayed (past full retirement age) claiming are designed to be actuarially fair. Thus on average in the US population, SSW is the same whether benefits are claimed at age sixty-two or seventy. Therefore, in the absence of growth in average lifetime earnings, the profile in SSW in figure 2.8 should be flat. The slight reduction in SSW between ages $65 / 66$ and 70 for early cohort men arises because the actuarial adjustment for delayed claiming beyond the full retirement age (65/66) was less than actuarially fair until 2005, when the 1943 birth cohort turned sixty-two. Thus, for the early HRS cohorts, there was a small actuarial penalty associated with delayed claiming. The slight average reduction for boomer men is likely a consequence of sampling variation. 


\begin{tabular}{lcc}
\hline & $\begin{array}{c}\text { Early } \\
\text { cohorts } \\
\end{array}$ & $\begin{array}{c}\text { Boomer } \\
\text { cohorts } \\
(1)\end{array}$ \\
\hline Married women & $22,547.0^{* * *}$ & $20,201.5^{* * *}$ \\
College educated & $(471.5)$ & $(652.2)$ \\
& $2,143.6^{* * *}$ & $1,035.80$ \\
Age at baseline & $(502.0)$ & $(708.7)$ \\
& $-865.5^{* * *}$ & $556.2^{* * *}$ \\
Earnings at baseline/1,000 & $(105.8)$ & $(165.0)$ \\
& $9.50^{* * *}$ & 0.14 \\
Hours worked per week at baseline & $(2.96)$ & $(2.72)$ \\
& $84.5^{* * *}$ & $92.5^{* * *}$ \\
Weeks worked per year at baseline & $(16.0)$ & $(23.4)$ \\
Job tenure at baseline & $159.7 * * *$ & 37.7 \\
& $(36.2)$ & $(45.3)$ \\
Lifetime number of years worked at baseline & -3.41 & -4.45 \\
& $(17.82)$ & $(27.94)$ \\
Black non-Hispanic & 34.4 & $-168.1^{* * *}$ \\
Hispanic & $(25.0)$ & $(40.5)$ \\
Other race/ethnicities & -561.4 & $(1,037.1$ \\
& $(734.8)$ & 1,300 \\
Fair/poor health at baseline & 903.4 & $(1,023.1)$ \\
& $(780.9)$ & $1,432.60$ \\
Observations & $2,144.2^{*}$ & $(1,497.1)$ \\
$R$-squared & $(1,116.7)$ & 352.1 \\
& -809.9 & $(833.7)$ \\
& $(589.9)$ & 1,692 \\
& 4,591 & 0.467 \\
\hline
\end{tabular}

Source: Health and Retirement Study (HRS) 1992 to 2012, RAND HRS Version O.

Notes: Dependent variable in all columns is change in Social Security wealth if work until age seventy. Social Security wealth (SSW) is the expected present discounted value of potential Social Security benefits earned on the individual's own record if he or she continued to work until claiming at age seventy. Models are OLS regressions and also include indicators for cohort and wealth quintile. Analysis sample contains married men and women who are ageeligible members of early cohorts (HRS-Late and War Babies) and boomer cohorts (Early Baby Boom, excluding Mid-Baby Boom). Data are structured in cross-sectional format such that units of observation are person-level. HRS respondent weights used. Standard errors in parentheses.

*** Significant at the 1 percent level.

**Significant at the 5 percent level.

*Significant at the 10 percent level. 
average than married men. But the Social Security benefit formula features a progressive replacement rate structure, and thus married women, at their present position in the lifetime earnings distribution, benefit from this progressivity.

Overall, these patterns reveal the discordant individual incentives facing married women and married men for continued work as they progress through their fifties and early sixties. However, it is possible that this discordance is weakened by the role of spouse and survivor benefits. I turn to this issue next.

\section{Household Social Security Wealth}

Under Social Security rules, married individuals are entitled to the larger of (a) a retired worker benefit based on their own work history, or (b) a spouse benefit equal to 50 percent of their spouse's retired worker benefit. Historically, nearly all recipients of spouse benefits have been married women, whose own benefit entitlement was less than 50 percent of their husband's benefit (and included many women who did not have enough work history to qualify for any benefit on their own record). Social Security rules also contain survivorship provisions. Widowed spouses are entitled to the larger of their own retirement benefit or a survivor benefit equal to 100 percent of their spouse's retirement benefit. As with spouse benefits, nearly all recipients of survivor benefits have been women. ${ }^{16}$

I approximate the proportion of women who would likely receive spouse benefits at each potential claiming age with the percent whose predicted SSW is less than 50 percent of their husband's predicted SSW. By this approximation, 44 percent of early cohort women would have received spouse benefits had they and their husbands both claimed at age sixty-two. If, instead, both worked and delayed claiming until age seventy, some 34 percent would have received spouse benefits. However, among boomer women, only 15 percent would receive spouse benefits if they and their husbands claimed at age sixty-two, and this would fall to just 11 percent with continued work until age seventy. ${ }^{17}$

Similarly, I approximate the proportion of women who would receive survivor's benefits if they became widowed by the percent whose predicted SSW is less than 100 percent of their husband's predicted SSW. By this approximation, 77 percent of early cohort women would have received survivor benefits upon widowhood if both spouses had claimed at age sixty-two. In contrast, continued work to age seventy would reduce this number to 65 percent. Among boomer women, far fewer-30 percent — would receive

16. Spouse and survivor benefits are also available to divorced women if the marriage lasted at least ten years and they have not remarried.

17. These approximations give rise to similar estimates by cohort as reported by the Social Security Administration (Iams 2016). 
survivor benefits in the event of widowhood if both spouses had claimed at age sixty-two, and continued work to age seventy would reduce the figure to 27 percent.

But do these gains in individual SSW have any effect on household-level SSW or do they simply crowd out SSW that was already held in the form of spouse and survivor entitlements? To assess this question I regress the gain in total household SSW - which as constructed by the HRS includes expected spouse and survivor benefit entitlements - on the potential change in individual SSW for the wife, and the potential change in individual SSW for the husband. Recall that any within-individual gain in SSW reflects the effect of added years of earnings, and so the marginal effect of an additional dollar of individual SSW indicates the degree to which this dollar matters for household SSW. Table 2.6 presents the coefficients from OLS regression models estimated separately by cohort group. Among the early cohorts, a one-dollar increase in the wife's individual SSW would have resulted in only ten cents additional household SSW - her SSW hardly matters. In contrast, a one-dollar increase in the husband's individual SSW would have yielded one dollar and thirty cents in additional household SSW, reflecting the incremental gains in spouse and survivor benefits based entirely on his earnings

Table 2.6

Effect of change in individual Social Security wealth (SSW) on change in household SSW

\begin{tabular}{lcc}
\hline & $\begin{array}{c}\text { Early } \\
\text { cohorts } \\
(1)\end{array}$ & $\begin{array}{c}\text { Boomer } \\
\text { cohorts } \\
(2)\end{array}$ \\
\hline Change in wife's individual SSW from 62 to 70 & $0.145^{* * *}$ & $\begin{array}{c}0.357^{* * *} \\
(0.040)\end{array}$ \\
Change in husband's individual SSW from 62 to 70 & $1.316^{* * *}$ & $0.867^{* * *}$ \\
& $(0.043)$ & $(0.039)$ \\
Observations & 1,547 & 590 \\
$R$-squared & 0.392 & 0.471 \\
\hline
\end{tabular}

Source: Health and Retirement Study (HRS) 1992 to 2012, RAND HRS Version O.

Notes: Standard errors in parentheses. Dependent variable in all columns is change in household-level Social Security wealth (SSW) between ages sixty-two and seventy if both spouses continue to work until age seventy. Models are OLS regression models. Individual SSW is the expected present discounted value of potential Social Security benefits earned on the individual's own record if he or she continued to work until the claiming age of seventy. Analysis sample is households of married women in the early cohorts (HRS-Late and War Babies) and boomer cohorts (Early Baby Boom, excluding Mid-Baby Boom). Data are structured in cross-sectional format such that units of observation are household level. Household Social Security wealth is the sum of each spouse's individual SSW, any SSW attributable to spouse benefits, and SSW attributable to survivor benefits. HRS respondent weights used. (For methodological details, see Kapinos et al. [2016] and Chien [2015].)

***Significant at the 1 percent level.

**Significant at the 5 percent level.

*Significant at the 10 percent level. 
Table 2.7

Percent retiring early by quartile of potential change in SSW from continued work

\begin{tabular}{lccccc}
\hline & \multicolumn{2}{c}{ Married women } & & \multicolumn{2}{c}{ Married men } \\
\cline { 2 - 3 } \cline { 5 - 6 } Gain quartile & $\begin{array}{c}\text { Mean of } \\
\text { gain quartile }\end{array}$ & $\begin{array}{c}\text { Percent } \\
\text { retiring early }\end{array}$ & & $\begin{array}{c}\text { Mean of } \\
\text { gain quartile }\end{array}$ & $\begin{array}{c}\text { Percent } \\
\text { retiring early }\end{array}$ \\
\hline 1 & 1,315 & 49.7 & & $-14,804$ & 42.0 \\
2 & 10,385 & 50.4 & & $-6,898$ & 43.9 \\
3 & 19,848 & 46.0 & & -817 & 43.3 \\
4 & 36,654 & 46.3 & & 10,782 & 39.4 \\
Observations & & 2,782 & & & 3,501 \\
\hline
\end{tabular}

Source: Health and Retirement Study (HRS) 1992 to 2012, RAND HRS Version O.

Notes: Percent retiring early is the percent who reduce work effort within eight years of their baseline wave. Social Security wealth (SSW) is the expected present discounted value of potential Social Security benefits earned on the individual's own record if he or she continued to work until claiming at age seventy. Analysis sample contains married men and women who are age-eligible members of early cohorts (HRS-Late and War Babies) and boomer cohorts (Early Baby Boom, excluding Mid-Baby Boom). Data are structured in cross-sectional format such that units of observation are person-level. HRS respondent weights used.

record for a large fraction of couples. However, the picture is quite different for the boomer cohorts: a one-dollar increase in the wife's individual SSW results in forty cents additional household SSW, while a one-dollar increase in the husband's individual SSW results in ninety cents additional household SSW. The earnings histories of married men continue to matter most, but by substantially less than before, as the earnings histories of married women begin to yield both individual and household-level benefits.

\section{Potential Gains and Retirement Decisions}

The potential gains in SSW from continued work are substantial, especially for married women, but an important question is whether women factor these potential gains into their employment decisions. To shed light on this question, I divide the potential gains in individual SSW from continued work to age seventy into quartiles. I then tabulate the percent of individuals in each quartile who are observed to "retire early"- that is, to reduce their work effort within eight years of baseline. This simple tabulation, presented in table 2.7, reveals very little correlation between the magnitude of the potential gain and the percent retiring early. For example, 49 percent of married women in the lowest potential gain quartile (with a mean gain in SSW of just $\$ 1,315$ ) subsequently retired early, and 46 percent of married women in the top potential gain quartile (with a mean gain of $\$ 36,654$ ) retired early. Interestingly, the pattern is similar for married men, although somewhat fewer married men retire early than married women: 42 percent of men in the bottom gain quartile (with a mean loss of $\$ 14,804$ ) retired early, while 39 percent of men in the top gain quartile (with a mean gain of $\$ 10,782$ ) retired 
early. These patterns suggest that potential gains in SSW do not factor into the retirement decisions of married women. This is also true for married men, whose earnings histories dominate the accrual of household SSW.

\subsection{Discussion and Conclusion}

This cross-cohort analysis of the employment patterns of married women has revealed several key findings. First, preferences for joint leisure persist among married women and men in recent cohorts, suggesting that the tradeoff between the potential return to continued work and preferences for joint leisure continues to be salient for couples. Second, married women in the boomer cohorts enter their early fifties earning 31 percent more than their predecessors in earlier cohorts. Married men in the boomer cohorts also earn more than their predecessors, but the growth across cohorts was 10 percent, notably less. Third, estimates of the shape of the age-earnings profiles for married women and men in their fifties indicate that the return to additional work is stable for women, but declining for men. Fourth, additional years of work beyond age sixty-two (the early retirement age), would make a measurable increase in the Social Security wealth of married women. This is because the additional years of earnings at these ages replace earlier years of lower or zero earnings in the retirement benefit computation formula. The same is not true for men, who would see little, if any, increase in Social Security wealth if they worked beyond age sixty-two, presumably because the additional years of earnings do not replace earlier years of lower earnings. Among the boomer cohorts, continued work places married women and married men on equal footing in terms of Social Security wealth by age seventy. Finally, I find that individuals with the largest potential gains in Social Security wealth are just as likely to retire early as those with the least to gain. Individuals, it appears, do not factor these potential gains into their employment decisions, and this raises the question of whether individuals are able to accurately assess the opportunity costs associated with reducing work effort before age seventy.

In sum, these patterns provide evidence that married couples face discordant incentives for continued work as they progress through their fifties and early sixties. My analysis has quantified one component of the important trade-off faced by older women as they decide whether or not to work longer-the opportunity cost associated with reducing work effort in tandem with their husbands. On the other side of this trade-off is the utility value placed on joint leisure.

Among married boomer women in their fifties, the opportunity cost of leaving the labor force early has risen as their earnings have grown. This opportunity cost is substantial and consists of both forgone earnings as well as incremental gains in Social Security wealth. Additional work beyond age sixty-two makes up for lower labor supply earlier in life, and can place 
married women on par with married men in terms of the lifetime resources available to them in the latter part of life. Increasingly, these additional resources will matter for the financial well-being of not just women themselves, but their husbands as well.

\section{References}

Arias, Elizabeth. 2002. "United States Life Tables, 2000.” National Vital Statistics Reports 51 (3), Washington, DC, National Center for Health Statistics. http://www .med.mcgill.ca/epidemiology/hanley/bios601/Lifetables/lifetb2000_01_06.pdf.

Baker, Michael. 2002. "The Retirement Behavior of Married Couples." Journal of Human Resources 37 (1): 1-34.

Banks, James, Richard Blundell, and Marıa Casanova Rivas. 2010. "The Dynamics of Retirement Behavior in Couples: Reduced-Form Evidence from England and the US." Unpublished manuscript, University of California, Los Angeles.

Blau, David M. 1998. "Labor Force Dynamics of Older Married Couples." Journal of Labor Economics 16:595-629.

Browning, Martin, and Pierre-Andre Chiappori. 1998. "Efficient Intra-Household Allocations: A General Characterization and Empirical Tests." Econometrica 66 (6): 1241-278.

Chien, Sandy, Nancy Campbell, Chris Chan, Orla Hayden, Michael Hurd, Regan Main, Joshua Mallett, et al. 2015. "RAND HRS Data Documentation, Version O.” Santa Monica, CA: RAND Labor \& Population Program, RAND Center for the Study of Aging.

Coile, Courtney. 2004. "Retirement Incentives and Couples' Retirement Decisions." B. E. Journal of Economic Analysis \& Policy 4 (1). Published online. DOI: https:// doi.org/10.2202/1538-0653.1277.

Gustman, Alan L., and Thomas L. Steinmeier. 2000. "Retirement in Dual Career Families: A Structural Model.” Journal of Labor Economics 18 (3): 503-45.

- 2004. "Social Security, Pensions and Retirement Behaviour within the Family." Journal of Applied Econometrics 19 (6): 723-37.

_. 2014. "Integrating Retirement Models: Understanding Household Retirement Decisions." In Factors Affecting Worker Well-Being: The Impact of Change in the Labor Market, Research in Labor Economics, vol. 40, edited by Solomon W. Polachek and Konstantinos Tatsiramos, 79-112. Bingley, UK: Emerald Group Publishing Limited.

Honoré, Bo E., and Áureo de Paula. 2014. "Joint Retirement in Europe.” Netspar Discussion Paper no. 10/2014-052, Network for Studies on Pension, Aging and Retirement. http://arno.uvt.nl/show.cgi?fid=135930.

Hurd, Michael D. 1990. "The Joint Retirement Decision of Husbands and Wives." In Issues in the Economics of Aging, edited by David A. Wise, 231-54. Chicago: University of Chicago Press.

Iams, Howard M. 2016. "Married Women's Projected Retirement Benefits: An Update." Social Security Bulletin 75 (2) 17-24.

Kapinos, Kandice, Charlie Brown, Michael Nolte, Helena Stolyarova, and David Weir. 2016. "Health and Retirement Study Prospective Social Security Wealth Measures of Pre-Retirees, Public Release Version 5.0: Data Description and Usage.” Ann Arbor: Survey Research Center, Institute for Social Research, Uni- 
versity of Michigan. http://hrsonline.isr.umich.edu/modules/meta/xyear/sswealth /desc/SSwealthP.pdf.

Lundberg, Shelly, and Robert A. Pollak. 1993. "Separate Spheres Bargaining and the Marriage Market.” Journal of Political Economy 101 (6): 988-1010.

Maestas, Nicole. 2001. "Labor, Love \& Leisure: Complementarity and the Timing of Retirement by Working Couples." PhD diss., Department of Economics, UC Berkeley.

Michaud, Pierre-Carl, and Frederic Vermeulen. 2011. "A Collective Labor Supply Model with Complementarities in Leisure: Identification and Estimation by Means of Panel Data." Labour Economics 18 (2): 159-67.

Schirle, Tammy. 2008. "Why Have the Labor Force Participation Rates of Older Men Increased since the Mid-1990s?" Journal of Labor Economics 26 (4): 549-94. 